\title{
Zawarcie małżeństwa mieszanego wyznaniowo według prawa małżeńskiego z 1836 roku
}

Normowanie małżeństwa mieszanego wyznaniowo nastręcza szereg trudności dla ustawodawcy uznającego religijny charakter instytucji małżeństwa. Regulacja musi bowiem uwzględniać często sprzeczne ze sobą przepisy prawa religijnego. Niekiedy pogodzenie zasad poszczególnych doktryn religijnych nie jest możliwe. Natomiast kompromisowe rozwiązania prawa państwowego stanowią jedynie nieporadne próby uchylenia kolizji przepisów religijnych. $\mathrm{Z}$ tego rodzaju problemem zetknął się również ustawodawca z $1836 \mathrm{r}$. Obowiązujący w Królestwie Kongresowym dekret - prawo o małżeństwie z 24 czerwca 1836 r. (Dz. Praw Tom XVIII, s. 57-297) uznawał małżeństwo za instytucję o religijnym charakterze. Regulację małżeństwa oparto na zasadach określonych w przepisach religijnych poszczególnych związków wyznaniowych. W dekrecie z 1836 r. wyodrębniono cztery rozdziały, w których zamieszczono przepisy dotyczące małżeństw w wyznaniach: rzymsko-katolickim, prawosławnym, greko-katolickim, ewangelicko-augsburskim i ewangelicko-reformowanym. Pozostałym wyznaniom, tak chrześcijańskim, jak i niechrześcijańskim, poświęcono rozdział $\mathrm{V}$.

W świetle prawa z 1836 r. nie mogło istnieć małżeństwo cywilne, które byłoby pozbawione skutku wyznaniowego. W konsekwencji regulacja małżeństwa musiała zostać oparta na zasadzie normatywnego zespolenia skutku wyznaniowego i cywilnego, a ustawodawca zmuszony był stworzyć mechanizmy mające na celu korelacje tych skutków. Dotyczyło to zarówno zawarcia, jak i rozwiązania małżeństwa. Zawarcie małżeństwa w świątyni określonego wyznania rozstrzygało do jakiego sądu będzie należało rozpoznanie kwestii jego ważności, a do 1891 r. miało zasadniczy wpływ na dopuszczalność rozwodu. Małżeństwom mieszanym poświęcono rozdział VI. W tym rozdziale zamieszczone zostały przepisy określające zasady skuteczności cywilnoprawnej małżeństwa zawieranego przez osoby należące do różnych wyznań.

Istotne znaczenie miała relacja prawa małżeńskiego z $1836 \mathrm{r}$. do prawa kanonicznego dominującego w Królestwie Kongresowym wyznania rzym- 
skokatolickiego. Prawo z 1836 r. w ślad za prawem kanonicznym przyjęło przeszkodę różności wiary (disparitas cultus), co powodowało, że z małżeństwem mieszanym można było się spotkać jedynie w dwóch przypadkach: w ramach wyznań chrześcijańskich i w ramach wyznań niechrześcijańskich ${ }^{1}$.

Prawo z 1836 r. nie przewidywało natomiast imp. mixtae religionis. Nie stwarzało zatem żadnych ograniczeń dla małżeństw mieszanych w ramach chrześcijaństwa, co stanowiło różnicę w stosunku do prawa kanonicznego. Regulacja ta w dużym stopniu odpowiadała stworzonemu przez ustawodawcę rozgraniczeniu związków mieszanych chrześcijańskich i niechrze-

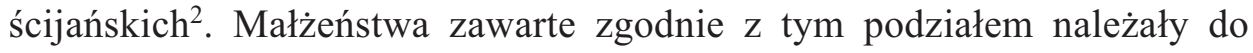
standardowych typów małżeństw mieszanych wyznaniowo. Natomiast małżeństwa nie poddające się temu podziałowi objęte zostały daleko idącymi restrykcjami. Przeszkoda różności wiary miała charakter przeszkody zrywającej iuris publici (art. 24 PM). Natomiast art. 415 obowiązującego w latach 1917-1932 kodeksu karnego z 1903 r. przewidywał, że „osoba wyznania chrześcijańskiego, winna zawarcia małżeństwa wbrew ustawie z osobą, o której było jej wiadomo, że nie jest wyznania chrześcijańskiego, ulegnie karze: aresztu"3.

Ponieważ konstytucja marcowa przewidywała wolność sumienia i wyznania (art. 111), kwestia zakazu zawierania małżeństw przez chrześcijan z nie-

${ }^{1}$ R. Longchamps de Berier, (w:) Matżeństwo w świetle nauki katolickiej. Praca zbiorowa Prof. Uniwersytetu Lubelskiego, Lublin 1928, s. 352.

${ }^{2}$ J.K. Wołowski, Kurs Kodexu Cywilnego, T. 1, Warszawa 1868, s. 79, podaje, że w oczach prawodawcy wszystkie negatywne następstwa małżeństwa mieszanego są mniejszego znaczenia, ,jeżeli różność religii w niektórych tylko jej dogmatach, albo też w sposobie oddawania czci zewnętrznej zachodzi, a w gruncie rzeczy na Chrześcijańskiem objawieniu się opiera [...]”. Według tego autora „niebezpieczeństwo byłoby o wiele większe gdyby związek małżeński mógł nastąpić pomiędzy osobą wyznającą jednę z Chrześcijańskich z osobą niechrześcijańskiej religii. Wpływ małżonka jednego na drugiego oraz na dzieci z małżeństwa zrodzone sprawićby mógł w takim razie iżby małżonek Chrześcijański przyjął religią swego współmałżonka, albo też żeby dzieci w tej religii wychwanemi a tem samem dobrodziejstw należenia do Chrześcijańskiego społeczeństwa pozbawionemi były. Prawodawca Chrześcijański nie chciał tego dopuścić; i dlatego też zgodnie z zasadami wszystkich chrześcijańskich wyznań małżeństwa takiego zabronił i takowe jeśliby zawartem było za nieważne ogłosił”.

${ }^{3}$ W. Makowski, Kodeks Karny obowiąujacy tymczasowo w Rzeczypospolitej Polskiej na ziemiach b. zaboru rosyjskiego..., T. 1, Warszawa 1921, s. 419-420, podaje, że przedmiotem tego przestępstwa była norma prawa familijnego, zakazująca chrześcijanom związków małżeńskich z niechrześcijanami (art. 24, 100, 133, 181 PM). Podmiotem może być tylko osoba wyznania chrześcijańskiego, wstępująca $\mathrm{w}$ związek z niechrześcijaninem. Niechrześcijanin odpowiedzialności nie ulega. Nie ulegają odpowiedzialności również duchowni oraz inne osoby współdziałające przy zawarciu małżeństwa (urzędnicy stanu cywilnego i świadkowie). Działanie przestępne polega na zawarciu związku małżeńskiego według form prawem przepisanych. Przestępstwo jest dokonane z chwilą, gdy związek małżeński w ten sposób zawarto. Działanie to powinno być zawinione umyślnie, tj. sprawca powinien wiedzieć, że osoba, z którą w związek małżeński wstępuje, nie należy do żadnego z wyznań chrześcijańskich. 
chrześcijanami stanęła pod znakiem zapytania. Niemniej, zawarcie małżeństwa z niechrześcijaninem na obszarze województw centralnych wiązało się z naruszeniem państwowego prawa małżeńskiego, które zachowywało moc obowiązującą do czasu uzgodnienia z konstytucją (art. 126 ust. 2 konstytucji). Uzgodnienie to w praktyce nigdy nie nastąpiło i w rezultacie dekret z $1836 \mathrm{r}$. obowiązywał do końca 1945 r.

Zasadnicze znaczenie dla małżeństw mieszanych wyznaniowo miały przepisy międzywyznaniowe dekretu z 1836 r. Prawo międzywyznaniowe opierało się zasadniczo na dwóch filarach, tj. wyróżniało dwie podstawowe konfiguracje małżeństw mieszanych wyznaniowo. W konsekwencji dekret przywiązywał duże znaczenie do zawarcia i rozwiązania małżeństwa mieszanego jedynie z przedstawicielami dwóch wyznań chrześcijańskich: rzymskokatolickiego oraz prawosławnego. Oba wyznania w pierwotnej redakcji dekretu uzyskały przywileje nadające im szczególną pozycję względem pozostałych wyznań. W tym sensie uprzywilejowanie obu wyznań równoważyło się, aczkolwiek zakres uprzywilejowania Kościoła prawosławnego był nieco szerszy. Nieco słabsza pozycja katolicyzmu względem prawosławia wyrażała się w następującej regule prawnej. W przypadku małżeństw z katolikami regulacja nie obejmuje tylko jednej konfiguracji międzywyznaniowej, a mianowicie, gdy współmałżonkiem katolika jest prawosławny. Takie małżeństwo nie zostało więc poddane dogmatom katolickim. Niemniej, małżeństwo ewangelika z katolikiem zawarte w świątyni katolickiej podlegało wyłącznej właściwości sądu katolickiego, a żaden z małżonków nie mógł uzyskać rozwodu (art. 197 PM). Z kolei przepisy dotyczące prawosławia odnosiły się do wszystkich konfiguracji małżeństw mieszanych z udziałem wyznawców tej religii, aczkolwiek względem katolików nie przyznawały wyrokom prawosławnego sądu duchownego skutków analogicznych jak w przypadku prawosławnych. W konsekwencji katolik rozwiedziony przez konsystorz prawosławny, aby zawrzeć kolejne małżeństwo, musiał ubiegać się o unieważnienie rozwiązanego już małżeństwa w sądzie swojego wyznania (art. $204 \mathrm{PM})^{4}$.

Skutki rozwodu prawosławnego zostały ujednolicone dopiero po nowelizacji prawa małżeńskiego z 1836 r., dokonanej przez zdanie Rady Państwa z 11/23 czerwca $1891 \mathrm{r}$. (Zb. ustaw i rozp. 1891 poz. 873). Znowelizowany art. 204 PM zakazywał katolikowi, po rozwodzie prawosławnym, występowania do sądu swojego wyznania. Jednolite skutki uzyskał także wyrok konsystorza ewangelickiego, którego właściwość w sprawie rozwodowej zależała odtąd od wyznania pozwanego (art. 196 PM w nowej redakcji). Nowelizacja ta nie miała jednak wpływu na przepisy o zawarciu małżeństwa przez osoby należące do różnych wyznań.

${ }^{4}$ H. Konic, Prawo matżeńskie obowiązujące w b. Królestwie Kongresowym, Warszawa 1924, s. 193. 
Właściwość sądu w przedmiocie ważności i rzeczywistego istnienia małżeństwa zależała od wyznania duchownego, który jako pierwszy udzielał ślubu (art. 196 PM). Nie mógł być to jednak dowolny duchowny. Prawo międzywyznaniowe regulowało właściwość duchownego w sprawie udzielenia ślubu skutecznego pod względem cywilnoprawnym. Prawo cywilne określało więc formę zawarcia małżeństwa. Regulacja tej kwestii nawiązywała do przepisów religijnych poszczególnych wyznań. Dla katolików przewidziano jako obowiązującą formę trydencką (proboszcz i dwóch świadków). Zawarcie małżeństwa w innej formie, choćby nawet dopuszczalnej w prawie kanonicznym, nie miało skutków w świetle prawa cywilnego.

Byt prawny małżeństwa chrześcijanina $\mathrm{z}$ niechrześcijaninem miał charakter wyjątkowy. Dotyczył przypadku przejścia jednego z małżonków niechrześcijańskich na chrześcijaństwo (art. 207 PM). Natomiast w ramach wyznań chrześcijańskich dopuszczalne były wszelkie małżeństwa mieszane, a prawo cywilne umożliwiało ich zawieranie nawet wbrew ustawie religijnej jednego z małżonków. Warunkiem cywilnoprawnej skuteczności chrześcijańskiego związku mieszanego była zatem jego ważność w świetle ustawy religijnej choćby jednego $\mathrm{z}$ małżonków. Przeciwnie, małżeństwa chrześcijan $\mathrm{z}$ niechrześcijanami ab initio były zawsze zakazane (art. 24 PM). W świetle prawa z 1836 r. zawarcie takiego małżeństwa nie było możliwe nawet wówczas, gdy dopuszczały to ustawy religijne obojga małżonków. Zakaz małżeństw chrześcijańsko-niechrześcijańskich nie miał zatem względnego, zależnego od stanowiska poszczególnych ustaw religijnych charakteru, lecz wynikał wprost z przepisów prawa cywilnego. Uzasadnia to wniosek, że ustawodawca dążył do zbiorczego ujęcia małżeństwa we wszystkich wyznaniach chrześcijańskich, eliminując wszelkie przeszkody uniemożliwiające osiągnięcie tego celu, a wyjątek czyniąc jedynie dla Cerkwi prawosławnej. Natomiast małżeństwa niechrześcijan zostały wyodrębnione jako samodzielna grupa związków religijnych, obdarzonych przez państwo skutecznością cywilnoprawną, z zastrzeżeniem ich monogamii.

Niektóre rozwiązania przyjęte $\mathrm{w}$ dekrecie z $1836 \mathrm{r}$. w zakresie regulacji małżeństw mieszanych korespondowały z katolickim prawem kanonicznym. Na uwagę zasługuje zwłaszcza podejście obu ustawodawstw do związków z niechrześcijanami. Natomiast ,różnica między pr. kan. a pr. cyw. - jak zaznaczał W. Jaworski - jest ta, że pierwsze mówi o ochrzczonych, drugie o chrześcijanach, pierwsze przeto zajmuje stanowisko, że chrzest wyciska niezmazalne piętno, jakiekolwiek dalsze koleje pod względem religji przechodziłaby osoba ochrzczona, drugie zaś, to jest pr. cyw. zajmuje to stanowisko, że rozstrzygającem jest, czy osoba w chwili zawierania małżeństwa przyznaje się do chrześcijaństwa, czy nie"5. Kwestię tę stawiano zresztą w li-

${ }^{5}$ W. Jaworski, Prawo cywilne na ziemiach polskich, T. 1, Prawo matżeńskie, Warszawa 1917, s. 88. 
teraturze przedmiotu bardziej zdecydowanie, twierdząc, że „co do małżeństw mieszanych zachodziła zdecydowana już nie różnica, ale i sprzeczność pomiędzy Prawem z 1836 r. a prawem kanonicznym. Reforma prawa kanonicznego (1907, a zwłaszcza 1917 r.) pogłębiła jeszcze te różnice" ${ }^{\text {. }} \mathrm{Z}$ tych między innymi względów podział małżeństw mieszanych przyjęty w Królestwie Kongresowym, połączony z korzystnymi rozwiązaniami dla mieszanych związków chrześcijańskich, generalnie nie przystawał do ustawodawstwa katolickiego, niechętnego wszelkiego rodzaju małżeństwom mieszanym.

W doktrynie katolickiej wyróżniano dwa rodzaje małżeństw mieszanych: katolików z tzw. heretykami i schizmatykami oraz z niechrześcijanami. Różnica pomiędzy nimi polegała na tym, że w ostatnim wypadku małżeństwo nie mogło być sakramentem. „Wedle pr. kan., kto raz został ochrzczony, nie może ważnie zawrzeć związku małż. z osobą nieochrzczoną, np. z żydówką, choćby przed zawarciem małżeństwa zmienił religję, a więc stał się np. bezwyznaniowcem"7. Ważność małżeństwa akatolickiego powinna być oceniona według prawa, które obowiązywało małżonków w chwili ślubu, na co wskazywano $\mathrm{w}$ przepisach dotyczących sądownictwa kościelnego ${ }^{8}$. Weredyk uważał, że charakter tego małżeństwa zależy od tego, czy było ono ważnie zawarte: jeżeli tak, to jest kontraktem naturalnym; jeżeli nie, to jest konkubinatem, określanym przezeń mianem nałożnictwa ${ }^{9}$. Małżeństwa z niechrześcijanami były przez katolicyzm zakazane pod sankcją nieważności ${ }^{10}$.

Najpoważniejszym problemem były mieszane związki chrześcijańskie. Związki te nabrały dla Kościoła rzymskokatolickiego dużego znaczenia. Kodeks prawa kanonicznego z 1917 r. przez małżeństwo mieszane (mixtae nuptiae) rozumiał wyłącznie małżeństwa zawierane pomiędzy osobami ochrzczonymi, z których jedna jest katolikiem, a druga akatolikiem ${ }^{11}$. W tym wypadku - jak słusznie stwierdzał W. Abraham - „nietrudno o kolizję pomiędzy dwoma różnemi prawami $\mathrm{w}$ zastosowaniu formy zawarcia małżeństwa, tak, że tej sprawy nie będzie można pozostawić wyłącznie prawu wyznaniowemu"12. W doktrynie międzywojennej dostrzegano zatem konieczność zastosowania w tym przedmiocie przepisów prawa państwowego.

${ }^{6}$ S. Grzybowski, I. Różański, Prawo małżeńskie. Komentarz, Kraków 1946, s. 4.

${ }^{7}$ W. Jaworski, Prawo cywilne..., s. 89.

${ }^{8}$ Przepisy o postępowaniu w sprawach o nieważność matżeństwa dla Sandomierskiego Sąu Biskupiego, oprac. Ks. Dr Józef Baron. Sandomierz 1938, s. 76.

${ }^{9}$ Weredyk, Wielka rana narodu polskiego czyli matżeństwo mieszane, Poznań 1906, s. 11.

${ }^{10}$ Weredyk, Wielka rana..., s. 11-14, podaje, że zakaz ten nie miał jednak absolutnego charakteru, wynikał bowiem z prawa przyrodzonego i kościelnego, a nie - mającego w doktrynie katolickiej najwyższą rangę - prawa bożego. Jeżeli zagrożenie zbawienia chrześcijanina nie ma miejsca, zakaz prawa przyrodzonego ustaje. Stąd papież może dyspensować od przeszkody prawa kościelnego, jeżeli uzna to za konieczne.

${ }^{11}$ Piotr Kałwa, (w:) Matżeństwo w świetle nauki katolickiej, s. 130-131.

${ }^{12} \mathrm{~W}$. Abraham, Zagadnienie kodyfikacji prawa matżeńskiego, PPA, LII, s. 158. 
Związki małżeńskie katolików z tzw. heretykami i schizmatykami nie były w prawie kanonicznym zakazane pod sankcją nieważności ${ }^{13}$. Zasadniczo jednak Kościół rzymskokatolicki, stojąc na gruncie własnych interesów, zwalczał tego rodzaju małżeństwa, uznając je za niewłaściwe ${ }^{14}$. Co jednak kryło się pod tymi niezwykle zagadkowymi zasadami? Przede wszystkim obawa przed utratą wiernych na rzecz konkurencyjnych Kościołów chrześcijańskich oraz zadawnione spory natury teologicznej. To były zasadnicze powody niechęci duchowieństwa katolickiego do małżeństw mieszanych ${ }^{15}$.

Prawo małżeńskie z $1836 \mathrm{r}$. w przypadku małżeństw z prawosławnymi przewidywało szereg niepodlegających korekcie obowiązków, a mianowicie małżeństwo musiało być zawierane w świątyni prawosławnej, a dzieci z niego zrodzone musiały być wychowywane także w tym wyznaniu (od wymogów tych odstąpiono dopiero po odzyskaniu niepodległości). Z katolickiego punktu widzenia małżeństwo z prawosławnym było więc z góry skazane na niepowodzenie, gdyż - jak stwierdzał Weredyk - ,tu chodzi o to, że taki prawosławny na warunki, stawiane przez kościół zgodzić się nie może, choćby i chciał, bo prawo państwowe zabrania mu tego bezwarunkowo"16.

Zawarcie małżeństwa $\mathrm{z}$ prawosławnym $\mathrm{w}$ świątyni jego wyznania byłoby sprzeczne z katolickim prawem kanonicznym. Toteż małżeństwu z prawosławnym katolicyzm nie dawał żadnej szansy:

„bo ani ślubu nie można wziąć z nim inaczej jak w cerkwi przed popem, ani on sam religii katolickiej pod ciężkimi karami przyjąć, ani dzieci po katolicku chrzcić i wychowywać nie ma prawa. Małżeństwo z prawosławnym jest bezwzględnym i prawdziwem nieszczęściem, to też kościół na nie nigdy nie może

${ }^{13}$ Weredyk, Wielka rana..., s. 11-14, podaje, że gdy,,żadna inna nie zachodzi przeszkoda, któraby takie małżeństwo unieważniała, będzie ono zawsze ważne, ale przytem niedozwolone, chyba że kościół na zawarcie jego udzieli pozwolenia, czyli dyspensy".

${ }^{14}$ Weredyk, Wielka rana..., s. 15, uzasadnia to stanowisko w następujący sposób: „Gdyby małżeństwo było instytucją czysto ludzką, kontraktem cywilnym, mającym na celu ziemskie doczesne interesa wtedy możnaby nie dbać o wiarę. - Ale małżeństwo jest instytucją Bożą, mającą charakter wybitnie religijny [...] Stąd wynika nieodzowna potrzeba, aby małżonkowie wyznawali jedną, jedynie prawdziwą, katolicką Religię..."

${ }_{15}$ Weredyk, Wielka rana..., s. 16, podaje: ,żeby przyjąć Sakrament należycie, trzeba go przyjmować od tego, komu Pan Jezus szafarstwo Sakramentów powierzył t.j. od przedstawiciela kościoła katolickiego i według przepisów tego kościoła, po za kościołem bowiem katolickim Sakramenta są nieważne albo co do istoty swojej, albo przynajmniej co do swych skutków. W tym ostatnim wypadku są one wprawdzie ważne co do istoty Sakramentu, ale są złączone ze świętokradztwem. Takie więc przyjęcie Sakramentu nie przynosi oczywiście do duszy tej łaski, którą z woli Pana Jezusa Sakrament jej miał udzielać, - więc będzie dla przyjmującego, jeśli jest katolikiem, złączonem z grzechem bardzo ciężkim, równającym się prawie odstępstwu od Kościoła. - W tym właśnie wypadku znajdują się wszyscy, którzy zawierają małżeństwo z prawosławnymi, albo z protestantami bez dyspensy papieskiej lub bez zachowania wymaganych przez kościół św. warunków".

${ }^{16}$ Ibidem, Wielka rana..., s. 26. 
się zgodzić, - chyba po za granicami państwa rosyjskiego, gdzie wymagane warunki można przyjąć i dochować”17.

Weredyk w tym względzie katolikom nie pozostawiał żadnych złudzeń, podkreślając, iż „takie małżeństwo, jako rzecz złą, uprawniać kościół nigdy nie może, - podobnie jak i rozłączać mniemanych małżonków; bo nie on ich połączył, i zresztą oni mu posłuszeństwo wypowiedzieli’"18.

W świetle doktryny katolickiej nie można było również rozdzielić elementu cywilnego i sakramentalnego (religijnego) związku małżeńskiego ${ }^{19}$. Skutkiem tego katolik i protestant, zawierając ze sobą związek małżeński, postrzegali instytucję, którą powoływali do życia w zupełnie innych kategoriach. $\mathrm{Na}$ ten problem także zwracał uwagę Weredyk, pisząc:

„Protestanci, nie uznając w małżeństwie Sakramentu nie uznają też jego nierozerwalności, według ich błędnej nauki, małżeństwo jest tylko kontraktem, czyli umową czysto ludzką, który dla lada przyczyny można zerwać i zawrzeć nowy z inną osobą. Gdy się, więc stronie protestanckiej z tej lub innej przyczyny, strona katolicka przestanie podobać, wyrobić ona sobie może z wielką łatwością rozwód w protestanckim konsystorzu i z kim innym wejść w nowy związek. Pod tym względem nie wiele lepiej jest u prawosławnych. U nich uznaje się rozerwalność małżeństwa w razie cudzołóstwa, albo też w razie cywilnej śmierci jednego z małżonków [...]. W ten sposób dzieje się krzywda nie tylko stronie katolickiej, która z takich rozwodów korzystać nie może - dzieciom, społeczeństwu i kościołowi - ale wyrządza się największą zniewagę Sakramentowi małżeństwa, skoro rozwiedziona strona akatolicka przez nowy cudzołożny związek depce go i znieważa..." ${ }^{20}$

Katolicyzm uznawał wyłącznie własną naukę o małżeństwie. Kościół rzymskokatolicki uważał bowiem, iż tylko on ,ma prawo autentycznie określać, na podstawie przepisów Boskiego prawa naturalnego i pozytywnego składniki istotne i własności wewnętrzne węzła małżeńskiego, t.j. jego jedność i nierozerwalność" ${ }^{21}$. Różnice dotyczące kwestii sakramentalności i nierozerwalności małżeństwa miały daleko idące skutki ${ }^{22}$. Pole kompromisu po-

${ }^{17}$ Ibidem, s. 26.

${ }^{18}$ Ibidem, s. 33.

19 Gommar Michiels, (w:) Matżeństwo w świetle nauki katolickiej, s. 81, podaje, że „Małżeństwo jest rzeczą świętą, sama umowa, przyzwolenie dwojga chrześcijan, dane na warunkach, przepisanych dla jego ważności, stanowi sakrament małżeństwa... Słowem, dla chrześcijan umowa małżeńska i sakrament są jedną i tą samą rzeczą, są bezwzględnie identyczne, gdyż mają tę samą materję i formę, tych samych szafarzy, do tego stopnia, że wszędzie gdzie jest umowa, jest przez to samo sakrament, i naodwrót, tak iż małżeństwo jest umową sakramentalną lub sakramentem umownym".

${ }^{20}$ Weredyk, Wielka rana ..., s. 33.

${ }^{21}$ Gommar Michiels, (w:) Matżeństwo w świetle nauki katolickiej, s. 86.

${ }^{22}$ Weredyk, Wielka rana..., s. 16, podaje, że ,natura każdego Sakramentu (a więc i małżeństwa) jest taka, że udziela on przyjmującemu go godnie tej łaski, jaką Pan Jezus do niego przy- 
między konkurencyjnymi doktrynami religijnymi nie było duże. Jak słusznie zaznaczono po 1945 r.,

„skutki rozbieżności pomiędzy prawem państwowym a prawem wyznaniowym nie byłyby same w sobie tak groźne, gdyby nie dalsze jeszcze rozbieżności, a mianowicie różnica, zachodząca pomiędzy prawami poszczególnych wyznań. Na skutek tych właśnie różnic sądy duchowne różnych wyznań rozstrzygały te same konkretne przypadki, i to rozstrzygały je odmiennie"23.

Małżeństwo z katolikiem zależało od spełnienia wymagań stawianych przez duchowieństwo. Warunki katolickie, obowiązujące obie strony (katolicką i niekatolicką), wiązały się z koniecznością złożenia przez akatolika pisemnego poręczenia, podpisanego przez świadków, że potomstwo będzie ochrzczone i wychowywane w wierze katolickiej oraz zobowiązania się tegoż małżonka do nieczynienia szykan na tle religijnym swemu współmałżonkowi katolickiemu i zrodzonym $\mathrm{z}$ ich związku dzieciom ${ }^{24}$. W kalwinizmie żądanie duchowieństwa rzymskokatolickiego co do składania przy ślubie deklaracji odnośnie do wychowania dzieci uważano za niegodny środek wpływania na wolę przyszłych małżonków, do którego uciekali się biskupi, nie mogąc tego uroszczenia poprzeć słowem bożym ${ }^{25}$. Niemniej, zastrzeżenie to nie było sprzeczne z prawem państwowym, jeżeli nie brać pod uwagę prawosławnych. Art. 195 PM co do zasady przewidywał, że synowie przyjmują wiarę ojców, a córki matek, dopuszczał jednak odrębne rozstrzygnięcie tej kwestii w drodze porozumienia między małżonkami. Porozumienie to stanowiło więc przedmiot wymagań kościelnych.

Małżeństwa protestancko-katolickie w świetle prawa cywilnego mogły być zawierane nawet wbrew stanowisku duchowieństwa rzymskokatolickiego. Z katolickiego punktu widzenia były ważne, lecz dopiero, „gdy kościół zezwala stają się one dozwolone i godziwe"26. Uzasadnieniem małżeństwa z protestantem była na ogół, znana prawu kanonicznemu, przyczyna niemoż-

wiązał, t.j. łaski Sakramentalnej. Żeby tej łaski dostąpić, trzeba przyjmować Sakrament godnie i należycie, a do tego trzeba być w stanie łaski poświęcającej. Ta zaś łaska wymaga, abyśmy byli w jedności kościelnej, i wierzyli we wszystko, w co wierzy i czego naucza kościół katolicki. Otóż strona niekatolicka nie wierzy we wszystko, w co wierzy kościół, a powtóre nie należy do jedności kościoła: więc łaski poświęcającej nie posiada, a tem samem ani wzrostu w tej łasce, ani łaski Sakramentalnej otrzymać nie jest w stanie".

${ }^{23}$ S. Grzybowski, I. Różański, Prawo matżeńskie. Komentarz, Kraków 1946, s. 4.

${ }^{24}$ W. Góralski, Matżeństwo kanoniczne, Warszawa 2011, s. 305, wskazuje, że obecnie strona niekatolicka nie składa żadnych zobowiązań i jest wyłącznie informowana o treści przyrzeczenia składanego przez stronę katolicką, że ta uczyni wszystko, co w jej mocy, aby wszystkie dzieci zostały ochrzczone i wychowane w Kościele katolickim.

${ }^{25}$ Tarcza wiary dla członków kościoła polskiego ewangelicko-reformowanego ułożona, wyd. II rozszerzone, Warszawa 1914-1920, s. 178.

${ }^{26}$ Weredyk, Wielka rana..., s. 24. 
ności znalezienia odpowiedniego kandydata na małżonka. Jeżeli zatem protestant, oświadczywszy się katoliczce, przyjmował wzmiankowane warunki, to władza kościelna z obawy, że ewentualna odmowa spowodowałaby porzucenie katolicyzmu, uznawała to za wystarczające do udzielenia dyspensy ${ }^{27}$.

Nie w każdym jednak wypadku Kościół rzymskokatolicki był tak samo skory do ustępstw. Przychylniej zatem traktowano związki innowierców z katoliczkami aniżeli katolików z akatoliczkami - chodziło oczywiście o to, żeby katolicka matka miała pieczę nad wychowaniem potomstwa. Chętniej również godzono się na małżeństwa $\mathrm{z}$ luteranami, kalwinów bowiem kler katolicki uważał za fanatycznych heretyków. Duże znaczenie miało także przyszłe zamieszkanie małżonków. Jeżeli mieścić się ono miało na terenach z przewagą ludności akatolickiej, dyspensy z reguły nie udzielano ${ }^{28}$.

Po przyjęciu warunków przez ewangelika, małżeństwo poprzedzały zapowiedzi z tą tylko różnicą, że przemilczano wyznanie religijne przyszłych małżonków. Kościół rzymskokatolicki nie życzył sobie, aby małżeństwom mieszanym nadawano rozgłos. Jeżeli zaś warunki zostały odrzucone przez akatolickiego narzeczonego, to wówczas zapowiedzi w Kościele rzymskokatolickim były zakazane. „Zapowiedzi bowiem głoszą się - jak zaznaczał Weredyk - w celu wykrycia przeszkód, jeśliby jakie były: tu zaś wykrywać nie ma potrzeby, bo są aż nadto widoczne, skoro wypływają z prawa Bożego i kościelnego" 29 . W tej sytuacji niemożliwe było spełnienie wymagania art. 43 PM, aby zapowiedzi ogłoszone zostały w parafii każdego z małżonków. Korekta przepisów o zapowiedziach była więc niezbędna. Rada Państwa postanowiła w 1905 r., że zapowiedzi mogą być głoszone jedynie w kościele protestanckim ${ }^{30}$.

Ustawodawca z 1836 r. zmuszony był wziąć pod uwagę dogmaty religijne przy konstruowaniu przepisów państwowego prawa międzywyznaniowego. Traktujący o małżeństwach mieszanych rozdział VI podzielony został na trzy oddziały. Pierwszy dotyczy małżeństw rzymskich katolików z osobami wyznającymi inną religię chrześcijańską ( $\mathrm{z}$ wyjątkiem prawosławia). Drugi poświęcony został małżeństwom osób wyznania prawosławnego z przedstawicielami in-

${ }^{27}$ Ibidem, s. 25.

${ }^{28}$ Ibidem, s. 26-27.

${ }^{29}$ Ibidem, s. 32.

${ }^{30}$ Według zdania Rady Państwa z dnia 14 III 1905 r. (Zb. 86/1905, poz. 704):

„1. Gdy zawarte zostały małżeństwa wedle obrządku protestanckiego między osobami wyznania protestanckiego i rzymsko-katolickiego, to zapowiedzi poprzedzające małżeństwo mogą być dokonane w samym tylko protestanckim kościele, ale w takim razie wstępujący w związki małżeńskie wyznania rzymsko-katolickiego z protestantami obowiązani są przedstawić władzy duchownej kościoła protestanckiego, w którym winny być dokonane zapowiedzi, w zamian przedślubnego świadectwa księdza rzymsko-katolickiego, zaświadczenie miejscowej policji, że nie znajdują się w stanie małżeńskim i że niema przeszkód do zawarcia małżeństwa.

2. Urzędnicy policji, wydając wyżej wskazane zaświadczenia, opierają się na metrykach urodzenia, na świadectwach o zamieszkaniu, książeczkach legitymacyjnych, a jeżeli niema możności przedstawienia wskazanych dokumentów, to na zeznaniach co najmniej dwóch świadków". 
nych wyznań oraz małżeństwom zawartym przed duchownym prawosławnym. Oddział trzeci regulował małżeństwo osób dokonujących zmiany wyznania. Oddział pierwszy podzielono na dwa pododdziały: o matżeństwach z osobami wyznań ewangelickich i o matżeństwach z osobami innych wyznań chrześciańskich. Zgodnie z art. 198 PM zasady zawarte w pododdziale pierwszym stosowały się do pododdziału drugiego. W rezultacie małżeństwo katolika $\mathrm{z}$ innym chrześcijaninem, wyjąwszy prawosławnego, podlegało takim samym zasadom, jak małżeństwo katolika $\mathrm{z}$ ewangelikiem.

Małżeństwo katolika z osobą innego wyznania chrześcijańskiego, z wyjątkiem prawosławnego, mogło być ważnie zawarte tylko przed duchownym wyznania narzeczonej (art. 192 PM). Jeżeli więc narzeczony ewangelicki nie chciał przyjąć stawianych warunków, małżeństwo nie mogło zostać zawarte. W odwrotnej sytuacji, tj. gdy narzeczoną była ewangeliczka, również dochodziło do niedającej się w żaden sposób usunąć kolizji pomiędzy państwowym prawem międzywyznaniowym a prawem kanonicznym. Wówczas nawet ubieganie się o dyspensę nie miało sensu, gdyż powołanym do udzielenia ślubu w myśl prawa państwowego był wyłącznie duchowny wyznania narzeczonej.

Bezkompromisowość Kościoła rzymskokatolickiego wiązała się z teologiczną specyfiką sakramentu małżeństwa ${ }^{31}$. Z tych względów nietrafnym pomysłem ustawodawcy był art. 193 PM. Przepis ten dozwalał na pobłogosławienie zawartego już związku przez duchownego wyznania narzeczonego; ceremonia ta miała jednak wymiar ściśle religijny i nie wywierała wpływu na kreację małżeństwa w prawie cywilnym ${ }^{32}$. Znaczenie tego przepisu polegało zatem na umożliwieniu ewangelikowi, który zawarł małżeństwo z katoliczką, dopełnienia kolejnej ceremonii ślubnej w świątyni ewangelickiej. Jednak z punktu widzenia doktryny katolickiej,

„Ślub, ważnie zawarty, nie może być nigdzie i nigdy powtórzony z tą samą osobą, tak samo jak Sakrament Chrztu, Bierzmowania i Kapłaństwa: byłoby to grzechem świętokradztwa. A jeżeliby ślub w kościele, dla jakich ukrytych przyczyn był nieważnie zawarty, to powtórzenie przed popem albo pastorem nie na wiele się przyda. - Brać ślub w akatolickiej świątyni, przed akatolickim duchownym

${ }^{31}$ Weredyk, Wielka rana..., s. 17, podaje, że ,ten kto z urzędu ma prawo udzielać drugim Sakramentów św. nazywa się ministrem Sakramentu. Ministrami 6 znanych Sakramentów są kapłani albo biskupi. Jeden tylko Sakrament małżeństwa różni się tem od innych, że jego ministrami nie są kapłani, ale sami małżonkowie. A kto jest ministrem Sakramentu, ten niech pamięta na przestrogę Zbawiciela: „nie dawajcie świętości psom, ani rzucajcie pereł waszych przed wieprze” (Mat. VII, 6). Stąd katolikom nie wolno brać z niekatolikami żadnego udziału w rzeczach religijnych, nabożeństwach, sakramentach, ceremoniach; akatolikom nie wolno administrować Sakramentów, ani też katolikom je od nich przyjmować. Tymczasem, zawierając małżeństwo z innowiercą, cóż robi strona katolicka? Oto stronie niekatolickiej administruje Sakrament małżeństwa i nawzajem od niej Sakrament ten przyjmuje. Jeżeli chodzi o protestanta, to się administruje Sakrament temu, który nawet weń nie wierzy - administruje się więc niegodnemu i niegodnie [...].”

${ }^{32}$ H. Konic, Prawo małżeńskie..., s. 116. 
katolikowi nie wolno nigdy i pod żadnym warunkiem, a to pod grzechem świętokradztwa i karą exkomuniki, zarezerwowanej samemu Papieżowi [...]".

Uzasadnieniem dla tak rygorystycznych poglądów były oczywiście różnice teologiczne. Postępowanie wbrew stanowisku Kościoła „byłoby ze strony katolika uczestnictwem $\mathrm{w}$ heretyckim kulcie religijnym (commuicatio in sacris) - byłoby uznaniem fałszu za prawdę Bożą: a więc byłoby świętokradzkiem znieważeniem Sakramentu - pod pewnym względem zaparciem się katolickiej Religii i kościoła"33.

Kościół rzymskokatolicki szczegółowo uregulował kwestię formy zawarcia małżeństwa w Dekrecie o Zaręczynach i Małżeństwie z 1907 r. ${ }^{34}$ Według niniejszego dekretu,

„Te tylko małżeństwa są ważne, które są zawierane wobec proboszcza lub Ordynaryusza, albo też kapłana delegowanego przez jednego z nich, oraz wobec dwu przynajmniej świadków..." (art. III).

\section{Art. XI § 1 głosił:}

„Prawami wyżej postanowionemi związani są wszyscy w kościele katolickim ochrzczeni oraz do niego nawróceni z herezji lub schizmy (chociażby czy to ci, czy to tamci od niego później się oderwali), ile razy będą zawierali między sobą zaręczyny lub zaślubiny".

\section{$\mathrm{W} \S 2$ czytamy:}

„Prawa te zachowują swą siłę także odnośnie tych katolików, o których wyżej, jeżeli zawierają zaręczyny lub zaślubiny z akatolikami, czy to ochrzczonymi, czy to nie ochrzczonymi, nawet po otrzymaniu dyspensy od przeszkody, pochodzącej z mieszanej religji lub nierówności kultu; chyba, że dla jakiej oddzielnej miejscowości byłoby inaczej od Stolicy świętej postanowione".

\section{Z kolei przepis $\S 3$ stanowił:}

„Akatolicy, czy to ochrzczeni, czy to nieochrzczeni, jeżeli między sobą się łączą, nie są nigdzie obowiązani do zachowywania katolickiej formy zaręczyn lub zaślubin".

Powyższe restrykcje miały jak najbardziej praktyczny wymiar, o czym świadczy korespondencja duchowieństwa katolickiego z władzami odrodzo-

${ }^{33}$ Weredyk, Wielka rana..., s. 33.

${ }^{34}$ Dekret o zaręczynach i matżeństwie z polecenia $i$ władzy Jego Świątobliw. Piusa X papieża Przez św. Kongregacyę Soboru wydany, Odbitka z Przeglądu Katolickiego za 1907 r. NN 37, 38 i 40. 
nej Polski, kwestionująca skuteczność małżeństw zawartych przed duchownymi prawosławnymi ${ }^{35}$.

Dekret Ne temere nie miał wpływu na obowiązujące w Polsce prawo cywilne. Na brak znaczenia tego dokumentu w stosunkach cywilnoprawnych wskazywali duchowni prawosławni. Włodzimierz, Biskup Warszawskiej i Chełmskiej Eparchji w piśmie do Ministerstwa W. R. i O. P. z dnia 2 IV 1921 r. informował:

„Podczas mojej ostatniej wizyty zimą było podjęte pytanie o tym, że niektórzy przedstawiciele rzymsko-katolickiego Duchowieństwa nie uznają prawnymi mięszane śluby, dokonane przez prawosławne duchowieństwo pomiędzy osobami wyznania prawosławnego a rzymsko-katolickiego. Pan Dyrektor Departamentu Wyznań zwrócił mi uwagę, że podobne czyny rzymsko-katolickiego duchowieństwa są nieprawne, ponieważ, wskutek uznanych w Polsce praw, mięszane śluby uznane prawnymi narówni ze ślubami, dokonanymi przez Duchowieństwo rzymsko-katolickie".

Dyrektor Piekarski wyparł się jednak tej wypowiedzi. Na niniejszym piśmie znajduje się bowiem podpisany przezeń, odręczny dopisek: „Takiego lub podobnego oświadczenia nigdy nie wyraziłem" ${ }^{36}$. Urzędnik odrodzonej Polski obawiał się zatem narazić biskupom katolickim.

Kodyfikacja prawa kanonicznego w 1917 r. utrzymała w mocy zasady dekretu kościelnego z 1907 r. W rezultacie w międzywojennej literaturze katolickiej różnice między prawem z 1836 r. a nowym prawem kanonicznym, dotyczące zawarcia małżeństwa mieszanego sprowadzono do trzech punktów:

1. prawo z 1836 r. nie uznaje różnicy wyznania jako przeszkody małżeńskiej, lecz tylko określa formę zawierania małżeństw mieszanych;

2. pozwala stronom na powtórny obrządek religijny, czego zabrania kan. 1063 ;

${ }^{35}$ AAN. Min. W. R. i O. P., 6/1177. W piśmie Proboszcza i Dziekana Nowogródzkiego do Starosty Nowogródzkiego z dnia 26 I 1921 r., czytamy: „Objeżdżając parafję moją, stwierdziłem liczne fakty mieszanych małżeństw prawosławnych z katoliczkami i odwrotnie zawartych w ostatnich latach zawieruchy wojennej w cerkwi prawosławnej, jak również w ostatnich czasach, co - raz częściej daje się stwierdzić łatwość ze strony duchownych prawosławnych błogosławienia takich małżeństw. Tymczasem na podstawie... dekretu o zaręczynach i małżeństwie.../p. III/ tego rodzaju małżeństwa dla strony katolickiej w sumieniu i prawie są żadne. Wobec tego stwarza się: 1 . Sytuacja ciężka pod względem moralnym dla strony katolickiej, gdyż uważaną być musi jako żyjąca bez ślubu i jako taka w kościele traktowana. 2. Sytuacja fałszywa pod względem prawnym i życiowym dla strony prawosławnej, gdy strona katolicka, idąc za nakazem kościoła i sumienia, stronę prawosławną opuści, a tembardziej, gdy będąc wolną prawnie w ponowne związki małżeńskie wstąpi. Donosząc o powyższem, uprzejmie proszę sprawę niniejszą w drodze urzędowej skierować do odpowiednich instancyj, skąd wyszłe odpowiednie zarządzenia szerzeniu się szkodliwych pod każdym względem małżeństw mieszanych zapobiegną".

${ }^{36}$ AAN. Min. W. R. i O. P., 18/1177. 
3. pozwala małżonkom układać się dobrowolnie co do religii przyszłego potomstwa bądź określa $\mathrm{z}$ góry wyznanie tego potomstwa, co stoi w sprzeczności z kan. $1061 \S 1$ p. $2^{37}$.

Ceremonia ślubna przed duchownym akatolickim została zabroniona przez wzmiankowany kan. 1063, stanowiący:

„Lubo od Kościoła została uzyskana dyspenza od przeszkody religii mieszanej, małżonkowie, ani przed zawarciem małżeństwa w obliczu Kościoła, ani po niem (ani przed ślubem ani po ślubie w kościele katolickim), nie mogą, czy to sami osobiście czy przez zastępcę, udawać się również do ministra akatolickiego, jako pełniącego służbę religijną, celem złożenia albo odnowienia konsensu małżeńskiego. Par. 2. Jeźliby proboszcz wiedział pewnie, że oblubieńcy złamią tę ustawę albo już złamali, nie ma asystować przy ich małżeństwie, chyba z przyczyn bardzo ważnych, po uchyleniu zgorszenia i poradzenia się wpierw ordynarjusza"38.

\section{W literaturze katolickiej odnośnie do § 2 stwierdzono:}

„Prawo kościelne zdaje się dopuszczać w pewnych wyjątkowych okolicznościach podwójne zawieranie związku małżeńskiego - raz w obliczu kościoła, i powtórnie wobec ministra akatolickiego; przez to jednak nie aprobuje postępowania strony katolickiej, zawierającej ślub podwójny, takie postępowanie z punktu widzenia prawa kościelnego jest zawsze przestępstwem, jedynie chodzi w tym przepisie o ewentualne salwowanie proboszcza katolickiego, gdyby ustawodawstwo świeckie za odmowę dania ślubu w podobnych okolicznościach nakładało na niego kary" 39 .

Ceremonia ślubna przed duchownym akatolickim obłożona została klątwą kościelną (kan. $2319 \S 1)^{40}$.

Nie potępia się jednak, że małżonkowie z nakazu prawa cywilnego stawiają się także przed ministrem akatolickim, sprawującym tylko powinność urzędnika stanu cywilnego i to jedynie dla dopełnienia aktu cywilnego ze względu na skutki cywilne (kan. 1063 §).

Prawo państwowe takiej możliwości jednak nie przewidywało, bo duchowny ewangelicki, wykonując funkcję z zakresu rejestracji stanu cywilnego, pełnił jednocześnie funkcję religijną, udzielając ślubu według obrządku

${ }^{37}$ J. Wiślicki, (w:) Matżeństwo w świetle nauki katolickiej, s. 158.

${ }^{38}$ Postanowienia Kodeksu prawa kanonicznego z 1917 r. w przekładzie zamieszczonym w dziele W. Jaworskiego, Prawo cywilne na ziemiach polskich, T. 1, Prawo matżeńskie, Warszawa 1917.

${ }^{39}$ J. Wiślicki, (w:) Matżeństwo w świetle nauki katolickiej, Lublin 1928, s. 149-150.

${ }^{40}$ W. Jaworski, Prawo cywilne na ziemiach polskich, s. 62. 
swojego wyznania (art. 192 PM). Natomiast w myśl art. 193 PM duchowny akatolicki, udzielając powtórnego ślubu, pełnił wyłącznie służbę religijną. Trudno jednak nie dostrzec, że postanowienia nowego prawa kanonicznego sugerują, jako możliwą do zaakceptowania, skądinąd dobrze znaną powojenną regułę: osobno ślub cywilny i kościelny. Aby bowiem zadośćuczynić postanowieniom kan. 1063, pastor musiałby pełnić wyłącznie rolę urzędnika państwowego i udzielić narzeczonym świeckiego ślubu cywilnego. Paradoksalnie więc kodeks kanoniczny wychodził naprzeciw optymalnemu rozwiązaniu, jakim były dla związków mieszanych śluby cywilne.

Próbą zaradzenia problemom teologicznym był kolejny przepis dekretu z 1836 r. Wyjątkowo zawarcie małżeństwa cywilnie skutecznego możliwe było także przed duchownym wyznania narzeczonego. Według art. 194 PM, „gdyby duchowny rzymsko-katolicki wzbraniał się dopełnić obrzędu ślubu religiynego małżeństwa pomiędzy osobami rzymsko-katolickiego i ewangelickiego wyznania, ślub danym bydź może przez duchownego ewangelickiego". Jeżeli więc narzeczoną była katoliczka, a przyszli małżonkowie nie mogli lub nie chcieli ubiegać się o pozwolenie władzy katolickiej, możliwe było zawarcie związku w Kościele ewangelickim. Warunkiem zawarcia małżeństwa w tym wypadku nie była odmowa udzielenia dyspensy, lecz zwykła odmowa duchownego katolickiego udzielenia ślubu. H. Konic stwierdził, iż w każdym innym przypadku udzielenia ślubu przez duchownego wyznania narzeczonego, ślub nie byłby ważny ${ }^{41}$.

Prawo z 1836 r. nie przewidywało imp. mixtae religionis, w konsekwencji nie mogło honorować katolickich reguł odnośnie do obowiązku występowania o dyspensę od tej przeszkody ${ }^{42}$. J. Wołowski w następujący sposób objaśniał motywy, które doprowadziły do powstania przepisu art. 194 PM:

„Prawodawca nie chciał przymuszać duchownych Katolickich, ażeby wbrew przepisom Kościelnym postępowali, ale tam, gdzie ze względów tolerancji i równouprawnienia wszystkich wyznań nie uznał za właściwe przepisom owym przyznać mocy, nie mógł dopuścić, ażeby opór duchownego Katolickiego mógł udaremnić jego wolę"43.

Ustawodawca umożliwił więc pominięcie przeszkody prawa kanonicznego, chociaż prawo to

„różnicę wyznania uznaje za rzecz tak ważną przy zawieraniu małżeństwa, że nie poprzestaje na prostym zakazie zawierania takich małżeństw, lecz różnicę ową kładzie pomiędzy przeszkodami małżeńskimi tamującemi, co pociąga za sobą tę

\footnotetext{
${ }^{41}$ H. Konic, Prawo matżeńskie..., s. 116.

${ }^{42}$ W. Jaworski, Prawo cywilne na ziemiach polskich, s. 63.

${ }^{43}$ J.K. Wołowski, Kurs..., s. 93.
} 
konsekwencję, że katolikowi nie wolno zawierać małżeństwa mieszanego, bez uzyskania dyspensy od władzy kościelnej”" ${ }^{44}$.

Kwestia zawarcia małżeństwa skutecznego prawno-cywilnie w sposób odmienny, aniżeli przewidywał to art. 192 PM, miała po odzyskaniu niepodległości istotne znaczenie praktyczne, wiązała się bowiem z kwestią właściwości sądu $\mathrm{W}$ sprawie stwierdzenia ważności małżeństwa. W tej kwestii rozstrzygał bowiem sąd wyznania, do którego należał duchowny dający jako pierwszy ślub (art. 196 PM). SN wyraził pogląd, iż

„decydującym [...] jest fakt, gdzie ślub był zawarty, nie zaś okoliczność, gdzie powinien być zawarty w myśl przepisu art. 192 PM, ten ostatni nie jest bowiem bezwzględny, skoro na mocy art. 194, o ile duchowny rzymsko-katolicki wzbrania się dopełnić obrzędu ślubu religijnego, ślub może być dany przez duchownego ewangelickiego. Wobec przepisów kanonicznych, wzbraniających zawierania małżeństw między osobami wyznającemi religję rz.-katolicką i osobami wyznania akatolickiwgo (kan. 1060, 1061, 1063), powołany art. 192 PM, o ile narzeczona jest wyznania rzymsko-katolickiego, w większości wypadków nie ma zastosowania..." (Zb. Orz. 172/1926).

Odnosząc się do powyższej tezy Sądu Najwyższego, E. Muszalski stwierdził, iż wskutek braku bezwzględnego charakteru, art. 192 dotyczy jedynie wypadku, gdy ślub winien być udzielony przez duchownego rzymsko-katolickiego ${ }^{45}$.

Powyższa konstatacja wiązała się jednak z faktyczną niemożnością zawarcia małżeństwa zgodnie $\mathrm{z}$ art. 192 PM, wówczas gdy narzeczona była katoliczką, a narzeczony akatolikiem. J. Wołowski i H. Konic zgodnie twierdzili, że art. 192 znajduje zastosowanie także w odwrotnej sytuacji. Art. 192 PM dotyczył zatem zawarcia małżeństwa przez katolika z akatolikiem bez względu na okoliczność, czy narzeczoną jest katoliczka, czy też akatoliczka ${ }^{46}$.

Unormowanie art. 194 PM, będące wyrazem dezaprobaty dla katolickiego stosunku do związków mieszanych, chociaż nie stanowiło recepty na pojawiające się kłopoty, miało pozytywny wydźwięk i w pełni zasługuje na miano postępowego rozwiązania $\mathrm{w}$ ramach państwowego prawa międzywyznaniowego. Zasadniczo jednak przyjęta $\mathrm{w}$ dekrecie z 1836 r. koncepcja właściwości duchownego wyznania narzeczonej była niefortunnym rozwiązaniem, wywołującym cały szereg problemów. Nowe prawo kanoniczne trudności te jedynie pogłębiło. Małżeństwa katolików z akatolikami od wejścia w życie 19 IV

${ }^{44}$ J. Wiślicki, (w:) Małżeństwo w świetle nauki katolickiej, s. 132.

${ }^{45}$ E. Muszalski, Prawo cywilne obowiazujące w b. Królestwie Kongresowem, Warszawa 1932, s. 110 .

${ }^{46}$ J.K. Wołowski, Kurs Kodexu Cywilnego, s. 93; H. Konic, Prawo matżeńskie..., s. 116. 
1908 r. dekretu „, Ne temere” zawarte bez formy kanonicznej były nieważne ${ }^{47}$. Obowiązujący od 19 V 1918 r. Kodeks prawa kanonicznego zasadę tę utrzymał w mocy (kan. 1099). Ponadto, kan. 1060 wprowadził zakaz małżeństw mieszanych, tj. katolika $\mathrm{z}$ ochrzczonym przedstawicielem innego zorganizowanego wyznania chrześcijańskiego (heretyckiego bądź schizmatyckiego). Natomiast małżeństwo pomiędzy katolikiem a katolikiem-apostatą, który nie wstąpił formalnie do którejkolwiek z sekt heretyckich czy schizmatyckich, nie było traktowane przez Kościół jako małżeństwo mieszane. Wprawdzie małżeństw tego rodzaju dotyczyły również zakazy kościelne, nie miały one jednak charakteru przeszkody tamującej ${ }^{48}$.

Według W. Abrahama, katolicyzm za katolików uważał osoby w tym kościele ochrzczone lub do katolicyzmu nawrócone, chociażby tak jedne, jak drugie, następnie od Kościoła katolickiego odstąpiły. Wobec tego byłyby „wskutek niezachowania katolickiej formy nieważne nie tylko małżeństwa pomiędzy katolikami a akatolikami, lecz także małżeństwa osób, które wiarę katolicką porzuciły, jeżeli pomiędzy sobą lub z innymi akatolikami związek małżeński zawierają"49. W konsekwencji małżeństwo zawarte zgodnie z art. 194 PM było kanonicznie nieważne, chociaż w obliczu państwa i Kościoła ewangelickiego było skuteczne. Nieważne kanonicznie było również małżeństwo zawarte w myśl art. 192 PM, jeżeli obrządku ślubnego dopełniał duchowny akatolicki, czego przecież nie można było uniknąć, jeżeli narzeczoną była akatoliczka. Kościół katolicki rościł sobie bowiem prawo do wszystkich, którzy zostali ochrzczeni, i sobie tylko przyznawał prawo do uwolnienia ich spod swych przepisów. Toteż heretycy i schizmatycy przestają podlegać jego władzy o tyle tylko, o ile sam Kościół nie chce jej nad nimi sprawowaćc ${ }^{50}$. Kościół katolicki nie wkraczał jednak w tę sferę i nie rozpatrywał ważności ich małżeństw, chyba że osoba katolicka chciała wstąpić w związki małżeńskie w Kościele katolickim z rozwiedzioną osobą akatolicką ${ }^{51}$.

Unieważnienia małżeństw zawartych w akatolickich świątyniach były po odzyskaniu niepodległości bardzo częste. W kręgach ewangelickich budziło to sprzeciw. Juliusz Bursche stwierdził:

„Kościół katolicki, wbrew prawu z 1836 roku dotychczas obowiązującemu, opierając się na prawie kanonicznym, sprzecznym z prawem cywilnym, unieważnia małżeństwa prawnie w kościele ewangelickim zawarte, jeżeli jedna ze stron była

${ }^{47}$ Przepisy o postępowaniu w sprawach o nieważność malżeństwa dla Sandomierskiego Sadu Biskupiego, oprac. Ks. Dr Józef Baron. s. 75.

${ }^{48}$ J. Wiślicki, (w:) Małżeństwo w świetle nauki katolickiej, s. 132-133.

${ }^{49} \mathrm{~W}$. Abraham, Zagadnienie kodyfikacji prawa malżeńskiego, PPA, LII, s. 24.

${ }^{50}$ Gommar Michiels, (w:) Matżeństwo w świetle nauki katolickiej, s. 98.

${ }^{51}$ Przepisy o postępowaniu w sprawach o nieważność matżeństwa dla Sandomierskiego Sadu Biskupiego, oprac. Ks. Dr Józef Baron, s. 75. 
wyznania katolickiego, czyli t. zw. małżeństwa mięszane, a rząd toleruje to bezprawie!"52

Ustawodawca nie uregulował natomiast zawarcia małżeństwa mieszanego wyznaniowo pomiędzy akatolikami, wyjąwszy przepisy dotyczące wyznania prawosławnego oraz wyznań ewangelickich. Prawo z 1836 r. nie zawiera postanowień normujących zawarcie małżeństwa np. kalwina $\mathrm{z}$ adwentystką.

Rozwiązania dotyczące wyznań ewangelickich wynikały z istnienia w czasie promulgacji prawa małżeńskiego z $1836 \mathrm{r}$. wspólnej organizacji kościelnej w postaci Generalnego Konsystorza dla wyznań ewangelickich w Królestwie Kongresowym. W rozdziale IV ustawodawca przewidział reguły zawarcia małżeństwa w wyznaniach ewangelickich. Małżeństwa kalwińsko-luterańskie potraktowane zostały jak związki jednolite wyznaniowo. Według art. 140 PM,

„ślub religiyny, danym bydź winien podług obrzędu wyznania ewangelickiego, do którego należą małżonkowie, w przytomności dwóch świadków przynaymniey, przez pastora gminy wstępujących w małżeństwo, a ieżeli bydź może, przez pastora narzeczoney. Wszakże dopełnienie obrzędu ślubnego przez pastora inney gminy, nie czyni małżeństwa nieważnem, ieżeli nie zachodzą powody nieważności prawem przewidziane".

W przeciwieństwie do małżeństw katolickich, małżeństwo ewangelickie mogło być zawarte przed dowolnie wybranym duchownym ewangelickim bez względu na zamieszkanie narzeczonych. Według art. 142 małżeństwo mogło być zawarte także w prywatnych domach. Art. 141 umożliwiał nawet zawarcie małżeństwa ewangelickiego przed duchownym rzymskokatolickim, ,jeżeliby $\mathrm{w}$ gminach administracyinych zamieszkania przyszłych małżonków, lub w gminach pobliskich, nie było pastora ewangelickiego".

Małżeństwa $\mathrm{w}$ ramach wyznań ewangelickich należy również zaszeregować do kategorii małżeństw mieszanych wyznaniowo. Oba wyznania pierwotnie posiadały wspólny Generalny Konsystorz, powołany przez Mikołaja I w 1828 r. Dopiero 20 lutego 1849 r. ten sam monarcha ustanowił w jego miejsce dwa odrębne konsystorze: ewangelicko-augsburski i ewangelicko-reformowany. W okresie międzywojennym wyodrębnienie to przypieczętowane zostało dekretem Prezydenta RP z 25 XI 1936 r. o stosunku Państwa do Kościoła Ewangelicko-Augsburskiego w RP (Dz. U. Nr 88 poz. 613).

Małżeństwo mieszane wyznaniowo nie stanowiło problemu dotyczącego wyłącznie obszaru Królestwa Kongresowego. Instytucja ta po odzyskaniu niepodległości stanowiła bowiem przedmiot zainteresowania nauki prawa w tych częściach państwa, w których obowiązywało ustawodawstwo uznające

\footnotetext{
${ }^{52}$ J.N. Baudouin de Curtenay, Wyznaniowe i pozawyznaniowe śluby i rozwody, 1927, s. 23.
} 
religijny charakter małżeństwa. Obszar ten stanowił zdecydowaną większość terytorium II Rzeczypospolitej. Kluczowe znaczenie miało, niechętne małżeństwom mieszanym, katolickie prawo kanoniczne, którego zasady w szeregu kwestiach były uwzględnione w ustawodawstwie państwowym. Dopiero unifikacja i sekularyzacja prawa małżeńskiego w 1946 r. zmarginalizowała problematykę małżeństwa mieszanego wyznaniowo i usunęła w cień zagadnienia związane $\mathrm{z}$ jego regulacją w ustawach państwowych.

\section{CONCLUSION OF INTER-DENOMINATIONAL MARRIAGE UNDER MARITAL LAW OF 1836}

\section{Summary}

The thesis discusses the significant question of inter-denominational marriages in Poland prior to 1946. Until the end of 1945, the laws in force in Poland were the $19^{\text {th }}$-century statutes. They had been enacted by the neighbouring countries (Austria, Russia and Prussia) that partitioned the Polish territory in the second half of the $18^{\text {th }}$ century. In the Polish lands enjoying some autonomy in the Russian Empire, the regulation of marriage was based on the religious principles of 1836 .

Under the 1836 statute, there could be no civil marriage that would not produce a confessional effect. Consequently, the regulation of marriage had to combine confessional and civil effects into single norms and the legislative authorities had to provide for mechanisms correlating such effects. This applied to both the conclusion and dissolution of marriage. In these matters, the Roman Catholic Church adopted an uncompromising stance following from its belief in the special theological character of the sacrament of marriage.

\section{CONCLUSION D'UN MARIAGE MIXTE INTERCONFESSIONNEL SELON LE DROIT DES RÉGIMES MATRIMONIAUX DE 1836}

\section{Résumé}

La dissertation traite d'une problématique essentielle pour la Pologne jusqu'à 1945, à savoir les mariages mixtes interconfessionnels. Jusqu'à la fin de cette année-là, sont en vigueur les lois publiées au XIXe siècle par les États qui, durant la deuxième moitié du XVIII ${ }^{\mathrm{e}}$ siècle, se sont partagé le territoire de l'ancienne Pologne (Autriche, Russie et Prusse). En 1836, la régulation du mariage sur le territoire polonais ayant conservé son autonomie dans les limites de l'État russe est basée sur les règles réligieuses. À la lumière du droit de 1836, le mariage civil sans effet confes- 
sionnel ne pouvait pas exister. Par conséquent, la régulation du mariage devait être basée sur le principe de fusion normative de l'effet confessionnel avec l'effet civil, le législateur étant obligé de créer des mécanismes permettant une correlation entre ces effets. Cela concernait tant la conclusion que la dissolution de mariage. L'intransigeance de l'église catholique romaine était liée à la spécificité théologique du sacrement du mariage. 